\title{
大規模公共体育館におけるアリー十空間の計画要件について
} （国立代々木競技場第一体育館における施設活用の分析より） 大規模公共体育施設の有効活用にむけた建築計画研究 その 1

\section{PLANNING FACTORS FOR ARENA SPACE IN LARGE-SCALE PUBLIC GYMNASIUM (ANALYSIS OF FACILITY UTILIZATION IN DAIICHI-TAIIKUKAN OF YOYOGI NATIONAL STADIUM)}

Study on architectural planning for effective utilization of large-scale public sports facilities Part 1

矢野裕 芳*，若色峰 郎** Hiroyoshi YANO and Mineo WAKAIRO

\begin{abstract}
This study aimed to identify planning factors that relate effective utilization of large-scale public gymnasium for athletic meets. In this topic, the utilization states of the arena space of Yoyogi National Stadium was surveyed. The following items were considered as planning factors to effective utilization of an arena space: 1) Duration of event 2) Features of spectators, number of spectators, number of days of using the facility, the ratio of "number of spectators" to "number of days of using the facility", and period necessary for preparation for each event 3) Kind of temporary equipment and places to install the equipment 4) Load carrying capacity of floor for installing the equipment, view from spectators' seats, methods of using lighting fixtures, and methods for installing scaffolds for the equipment 5) Heavy-duty zone to install large equipment used in the event
\end{abstract}

Keywords : Large-scale Public Gymnasium for athletic meets, Arena Space, Planning Factors, Yoyogi National Stadium, Facility Utilization, Large-scale Public Sports Facilities, Effective Utilization

大会用の大規模公共体育館、アリーナ空間、計画要件、国立代々木競技場、施設活用、大規模公共体育施設、有効活用

\section{1、研究背景・目的}

オリンピックやワールドカップなどの国際大会や国内選手権を 開催する大規模公共体育施設は、大会用に設置され文、公式のア リーナや多数のスタンド席が整備されている。しかし、これら大 会は、一般に、開催頻度が少ないため、施設本来の機能規模を日 常的に十分発揮する機会が少ない。そのため、こうした施設では、 大会が無いときには、各種のスポーツや催物（以下、開催種目） によって活用していくことが求められている文2。

本研究は、我が国における大規模公共体育施設の初期事例とし て、1964 年に開設された国立代々木競技場第一体育館を対象とし、 そこでの施設活用実態を調査分析し、施設の有効活用注 1 に関わる 運営上・設計上の計画要件注 2 につて考察することを目的として いる。本研究は三編で構成される。本編ではアリ一ナ空間（アリ 一ナ・観客席を含めた体育館の競技空間）の使われ方に着目し、 アリーナにおける開催種目とアリーナ空間との関係性を明らかに し、アリーナ空間の計画要件について考察する。第二編では主催 関係者用のサービス空間注 3 の使われ方に着目し、開催種目とサー ビス空間との関係性を明らかにし、その計画要件について考察す る。第三編では屋外空間注 4 の使われ方に着目し、開催種目と屋外 空間との関係性を明らかにし、その計画要件について考察する。
各編を通して、開催種目と施設機能との関係性を、運用面や活 用面から分析し、建築計画に関する一資料を提供するものである。 なお、これまでに大規模公共体育館の事例を紹介する文献文 3 や変 遷に関する研究文 ${ }^{4}$ は散見されるが、本研究のように、大規模公共 体育施設の有効活用に視座を置く実証的な研究は見当たらない。

\section{2、研究対象}

大規模公共体育館における施設活用の実態を、具体的な資料や 施設管理者の証言をもとに調查分析し、施設の有効活用に関わる 計画要件を明らかにすることは、これら施設を計画・設計・運営 する人々にとって意義あることと思われる。それは長年に渡って 各種のスポーツ競技や催物を開催し、その開催技術や運営技術を 生かしながら施設を運用し、維持管理している大規模公共体育施 設を詳しく調查することによって初めて明らかになるものである。 そうした取り組みを続けているのが、国立代々木競技場第一体 育館（以下、第一体育館）である。類似施設は多々あるが、第一 体育館を研究対象とした理由は、(1)我が国初の公式な屋内総合競 技場注 5 であり、そこで競技大会の代表格であるオリンピックを開 催し、現在も各種の国際スポーツ競技や選手権などの大会を頻繁 に行っていること、(2)計画当初より、アリーナの場面転換を想定
* 日本大学大学院理工学研究科建築学専攻 博士後期課程

** 日本大学理工学部建築学科 教授・博士 (工学)
Graduate Student, Dept. of Architecture, Graduate School of Science \& Technology, Nihon University

Prof., Dept. of Architecture, College of Science \& Technology, Nihon University, Dr. Eng. 




し社6、大会が無いときには、各種のスポーツや催物を行い、活用 していくことを目指した施設注 7 であること、(3)約 40 年に渡る運 営実績を持ち、その間の施設管理記録や催物対応記録が整備され ていること、(4)施設活用を進めるにあたり、これまでに様々な施 設面・運営面の改善を行っている注 8 こ、(5)夏季は体育館、冬季 はアイススケート場として通年利用されていること、(6)約 1 万 3 千人を収容する大規模公共体育館であること、(7)著名建築社 9 だが、 施設活用の実態については殆ど解明されていないこと、(8)本研究 への理解と協力が得られたこと、などがある。

つまり、第一体育館は、大会用の大規模公共体育施設であるが、 長期にわたり、時代の動きに合わせながら、大会以外の各種催物 にも対応し、施設を運用し、活用し続けている類稀な大規模公共 体育館注 10 である。これは、競技大会に基軸を置く大規模公共体 育施設をつくり、運営していくときには極めて重要な視点であり、 こうした第一体育館の施設活用実態を様々な角度から分析し、施 設の有効活用に関わる計画要件について考察することは、今後、 競技大会用の体育施設を計画するときの参考になるものと考えた。 図ー1 に第一体育館の建築概要注 11 、注 12 を示す。

\section{3、調査概要 (表-1)}

大規模公共体育施設は、本来、スポーツ団体などへの施設貸し 出しが主たる事業であるため、アリーナ専用利用の開催種目を調 查対象とした。調查は、施設管理者が記録保管している運営資料 や催物開催資料の分析を中心とするが、それら内容や施設の対応 方法を確認するために、施設管理者へのヒアリング調査と施設調 査、開催種目の会場見学と記録ビデオの視聴を行った。

\section{4、アリーナ空間の活用状況}

まず、これまでの開催種目の変遷を分析し、次に、その延長に ある近年（2002 年度）の開催種目をケーススタディとして、その 種類·観客層や観客数・施設利用日数や利用時間などを分析する。

表一1 謂查㨽要

\begin{tabular}{|c|c|}
\hline \multirow[t]{2}{*}{ 繁料調查(1) } & 期間 2000 年 4 月～2002 年 3 月 \\
\hline & 内容にれまでの開慛理目、施設の利用日数・入場者数、施設案内書等 \\
\hline \multirow[t]{2}{*}{ 皘料調查(2) } & 期間 2003 年 4 月 9 月 \\
\hline & $\begin{array}{l}2002 \text { 年度の催物開摧記録(施設の利用日数·利用者数、催物の開 } \\
\text { 内容婎資料、施設図、施設案内書等) }\end{array}$ \\
\hline \multirow[t]{2}{*}{ ヒアリング調査 } & 期間 2003 年 8 月 2004 年 3 月 \\
\hline & \begin{tabular}{l|l} 
& $\begin{array}{l}\text { 会場設営時の施設対応について(アリーナ動線、空間の見切り方、 } \\
\text { 内容床荷重な゙゙33 項目) }\end{array}$ \\
\end{tabular} \\
\hline \multirow[t]{2}{*}{ 施設調查·見学 } & 期間 2002 年 7 月 2004 年 6 月 \\
\hline & \begin{tabular}{l|l} 
& スポーツ大会などの見学、施設管理者同行による施設調查、催物記 \\
内容録ビデオによる開催状涗の確鿁
\end{tabular} \\
\hline
\end{tabular}

\section{4-(1) 開催種目の変遷}

表ー2 は、開館以降の運営記録をもとに、過去 39 年間の開催種 目を事業年度別に分類整理したもの文5である。印は、当該年度 に 1 回以上出現した開催種目であり、表中の「場面」はアリーナ の転換場面、「区分」はアリーナの利用区分、「部門」はアリーナ の利用部門、「グループ」は開催種目の類型を示す。アリーナ利用 の歴史は、アイススケート場と水泳場の 2 場面を持つ第一期 (1964 年〜1975 年)、アイススケート場と水泳場と体育館の 3 場面を持 つ第二期（1976 年～1997 年）、アイススケート場と体育館の 2 場 面を持つ第三期（1998 年以降）に大別する事ができる注 13 。その 間、アイススケート場への場面転換は毎年行われ、水泳場は 1998 年度以降中止されている。これまでの開催種目（グループ数）は 計 65 種類である。各期における事業年度あたりの平均開催種目数 は、第一期が約 6 種類 $(64 / 12)$ 、第二期が約 15 種類 (321/22)、 第三期も 15 種類（72/5）である。開催種目の多い体育館場面がア リーナの活用巾を公げている。一方、30 年以上存続する開催種目 はアイススケート場の自由滑走（個人利用）やアイスホッケーな ど 4 種類である。また、20 年以上（29 年以下）はフィギヤスケー ト・バレーボール・ポップスコンサートの 3 種類であり、10 年以 上（19 年以下）はミニバスケットやテニスなど 8 種類である。そ して、10 年未満は 50 種類あり、全体の約 8 割（50/65）を占める。 開催種目の多くは存続期間が短く、出現・消滅も激しい事が判る。 


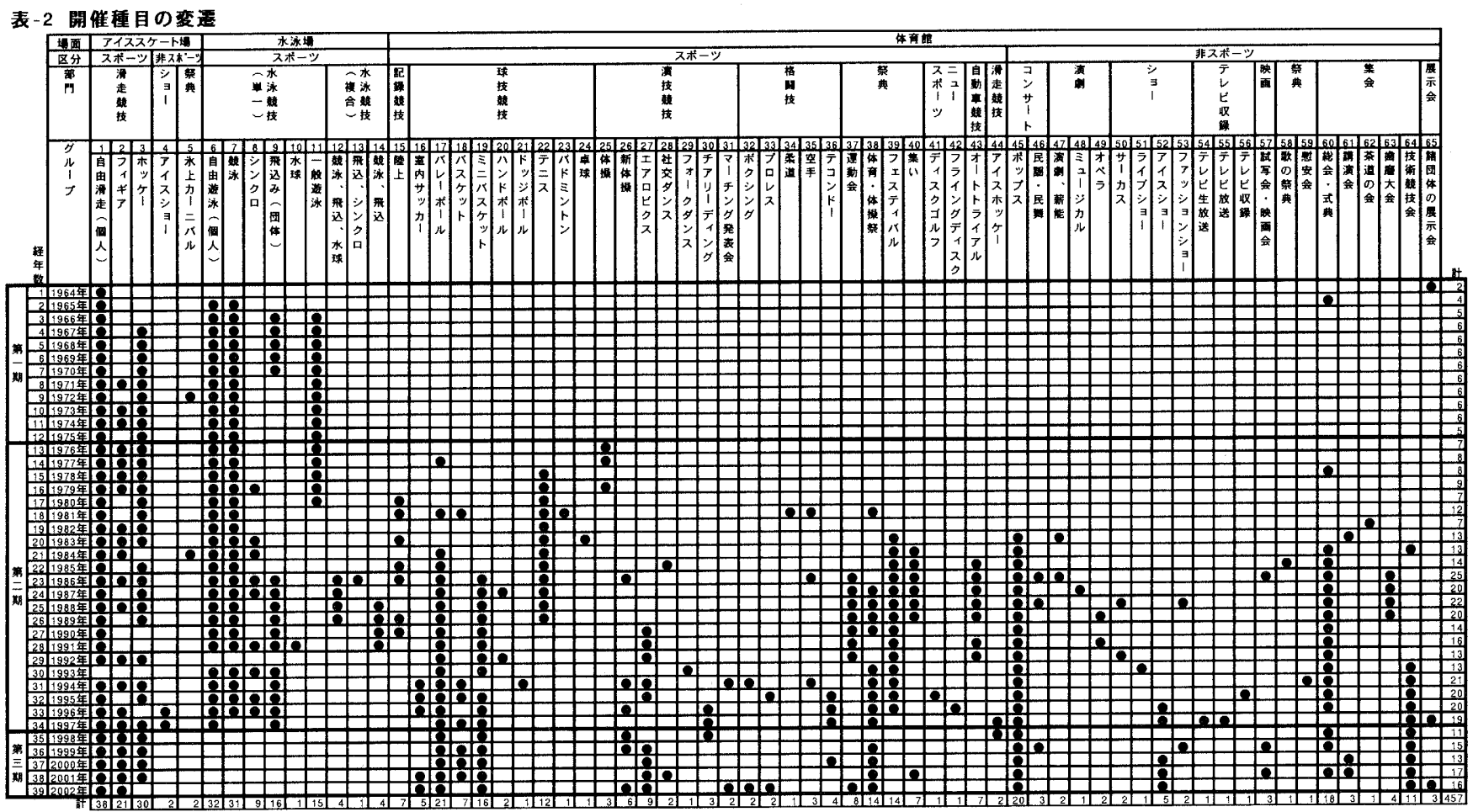

\section{4- (2) 2002 年度の開催種目}

(1)開催種目の種類と観客層との関係（表一3）

開催種目は全部で 34 種類あり、「スポーツ系の開催種目(以下、 スポーツ系)」が 6 割 (20/34)、「非スポーツ系の開催種目 (以下、 非スポーツ系)」が 4 割（14/34）である。うち、公認の競技大会 は全体の約 2 割（7/34）、最多はコンサートの約 3 割（11/34）で ある。「スポーツ系」は世界リーグから企業の運動会、競技大会か ら遊びの催物、女性スポーツから障害者スポーツまであり、その 施設利用者は、スポーツ団体・学校・企業などで構成され、出場 者にはアマチュアやプロがいるなど複雑だが、「非スポーツ系」は ポップスコンサートやミュージカル、コンクールや見本市などで あり、主な施設利用者は企業で構成され、出場者もプロが多いた め、比較的にシンプルである。一方、観客層は、「スポーツ系」で は大半（但し、女性スポーツのフットサルや新体操を除く）が男 女半々で 3 才から 70 才代、そして、10才代から 40 才代が中心で あるのに対して、「非スポーツ系」では大半が 10 才代から 30 才代 の女性である。アリーナは、スポーツ関係者が多い公認競技大会 よりも、幅広い観客層が多い「スポーツ系」や特化した観客層が 多い「非スポーツ系」の開催種目で活用されていることが判る。

\section{(2)観客数と施設利用日数との関係 (図-2)}

アリーナの年間観客数（有料・無料の一般観客数の合計）は約 105 万人であり、年間施設利用日数（準備日・本行日 ・撤去日の 合計）は 185 日である。いずれも約 9 割が球技・祭典・コンサー トの 3 部門で占められている。一方、年間観客数比率が年間施設 利用日数比率を上回るもの、すなわち、施設利用日数の割には観 客数が多い開催種目は、コンサート・ショー・格闘技などの興行 である。コンサートは、年間観客数や年間施設利用日数が多いだ けでなく、年間の客席利用率注 14 も高いことが判る。そうした年 間観客数や年間施設利用日数が多い開催種目、施設利用日数の割 には観客数が多い開催種目がアリ一ナ活用の主体となっている。


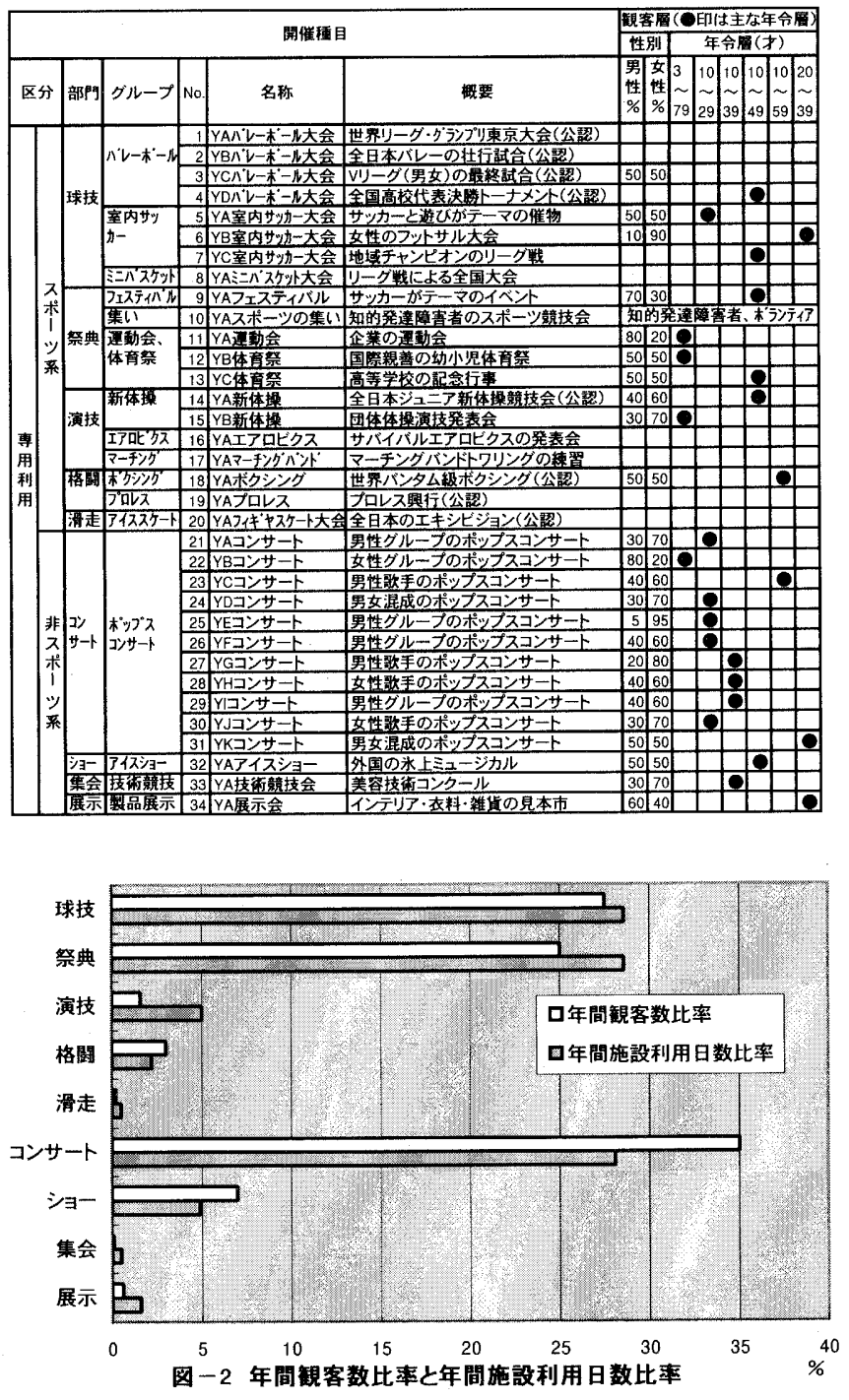


\section{(3)一回あたりの開催時間と篗客数との関係}

ここで言う一回あたりの開催時間とは、各開催種目の開催一回 あたりの開場時刻から終了時刻迄の延時間であり、観客数とは、 その間の一般観客数（有料・無料）の合計である。但し、数日間 行われる競技などの場合には、各開催時間の合計と各観客数の合 計を開催回数で割った数值としている。調査対象は、それら記録 が示された開催種目であり、「スポーツ系」が 16 （一部 19）、「非 スポーツ系」が 14 の計 30 例主 15 で全体の 88\%（30/34）である。

「スポーツ系（図一3）」は、開催時間が 7 時間前後で観客数が 4,000人前後のものが多い。また、「非スポーツ系（図一4）」は、 開催時間が 4 時間前後で、観客数が 10,000 人前後のものが多い。 収容定員は、スタンド席が 9,079 人、アリーナ席が 4,586 人の計 13,665 人であることから、平均的には、「スポーツ系」がスタンド

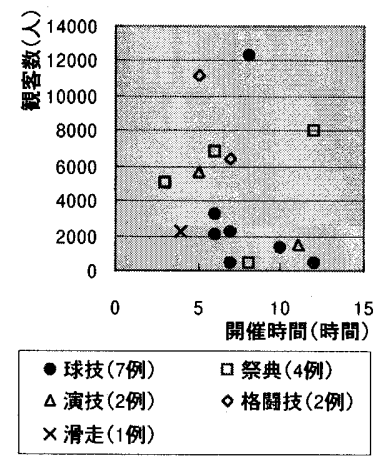

図-3 スポーツ系理目 (16例) の1回あたり開催時間と钼客数

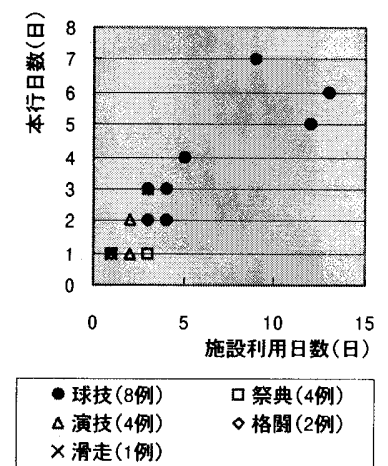

图-5 スポーツ系理目(19例) の1回あたり施設利用日数と本 行日数

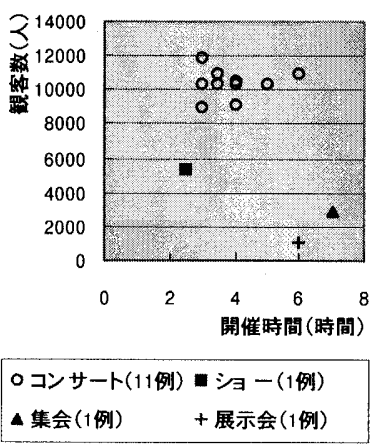

图 - 4 非スポーツ系理目(14 例) 1 回あたり開催時間と観客数

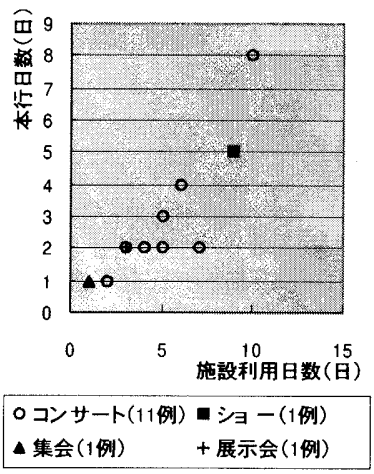

図-6 非スポーツ系理目(14 例)の1回あたり施設利用日数と 本行日数
席の約半数、「非スポーツ系」がスタンド席とアリーナ席の約 7 割 を使用していることになる。「非スポーツ系」の開催種目には、ア リ一ナ空間の収容定員を概ね使い切るものが多いことが判る。

\section{(4)一回あたりの施設利用日数と本行日数との関係}

ここで言う、一回あたりの施設利用日数とは、各開催種目にお ける開催一回あたりの設営撤去日数と本行日数（本番日数）の合 計である。「スポーツ系（図一5）」・「非スポーツ系（図一6）」の 施設利用日数と本行日数との間には、いずれも正の比例関係が見 られる。しかし、「スポーツ系」は、施設利用日数と本行日数がほ ぼ似通っているものが多いが、「非スポーツ系」は、施設利用日数 が本行日数の 2 倍前後であるものが多い。これは、開催種目の設 営撤去期間や練習（リハーサル）期間の違いによるものである。 設営撤去期間は、アリーナの非公開期間となることから、アリー ナの公開性や活用性から見ると少ない方が望ましい。設営撤去期 間の短縮化はアリーナ空間活用上の一課題であると思われる。

\section{5、設営機材の設置とアリーナ機能との関係（2002 年度の場合）}

開催種目の実施には、各種の機器や資材が必要であり、施設側 は、それらを受け入れ、十分に設置対応できるかどうかがアリー ナ空間の活用には極めて重要である。そこで次は、アリーナにお ける設営機材の種類・設置場所・設置方法に注目し、アリ一ナ機 能との関係性を分析する。調查対象は、設営機材の内容が示され た 25 件の開催種目であり、全開催種目の $74 \%$ （25/34）である。 5-(1) 設営機材の定義

設営機材には、競技用や舞台用、大道具や小道具、移動式や固 定式、重量物や軽量物など、様々なものがある。ここでは、そう した中でも、比較的に大型で重量のある機器や資材で、現場組立 てを必要とし、アリーナ機能や使い勝手と直接的に関わり合う、 例えば、アリーナ計画における開催種目の見せ方や荷重設定に影 響を及ぼす仮設の機材や設備のことを設営機材と定義しておく。

5-(2) 設営機材の種類と設置場所との関係（表 -4）

設営機材は、計 60 種類あり、コートやステージなどの項目に 分類することが出来、その設置場所は、アリーナやスタンド席な ぞに大別することが出来る。全開催種目に共通する設営機材は、 機器用の露出配線・電源盤・施設開口部用の暗幕である。施設側 の常設備品は、平置型客席 (パイプ椅子) や黒幕であり、それ以 外は、主催者側の持込品である。「スポーツ系」では、設営機材の

表-4 設営機材の種類と設置場所

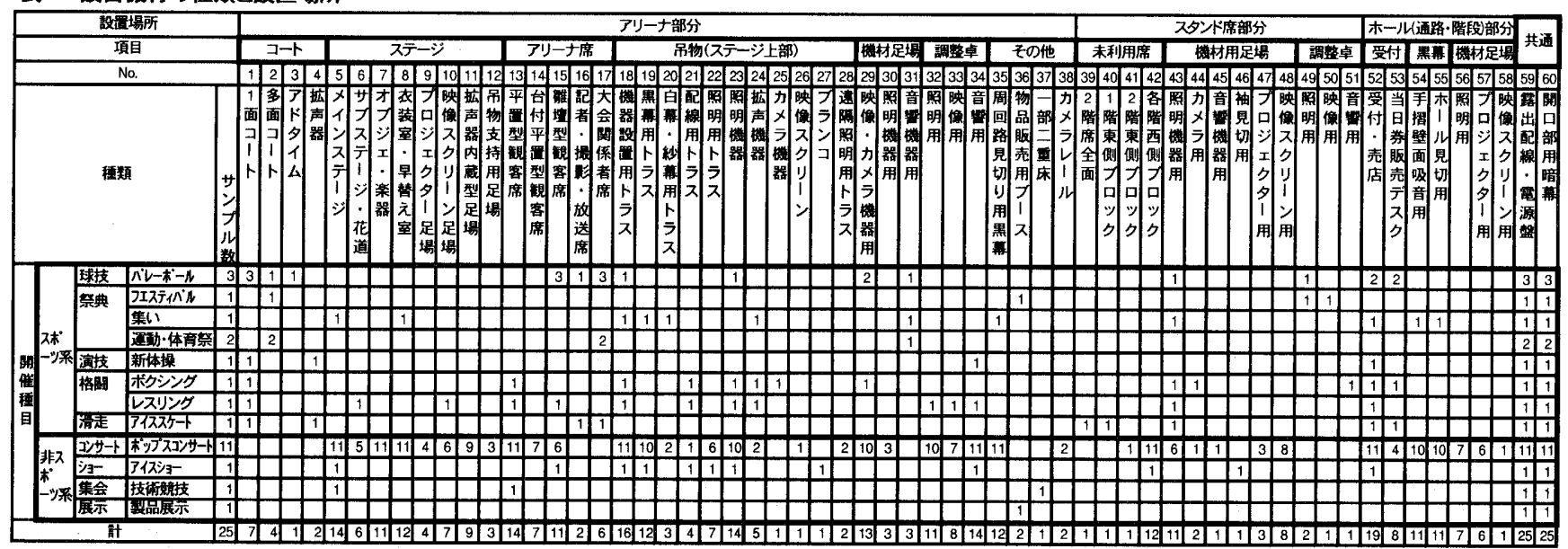




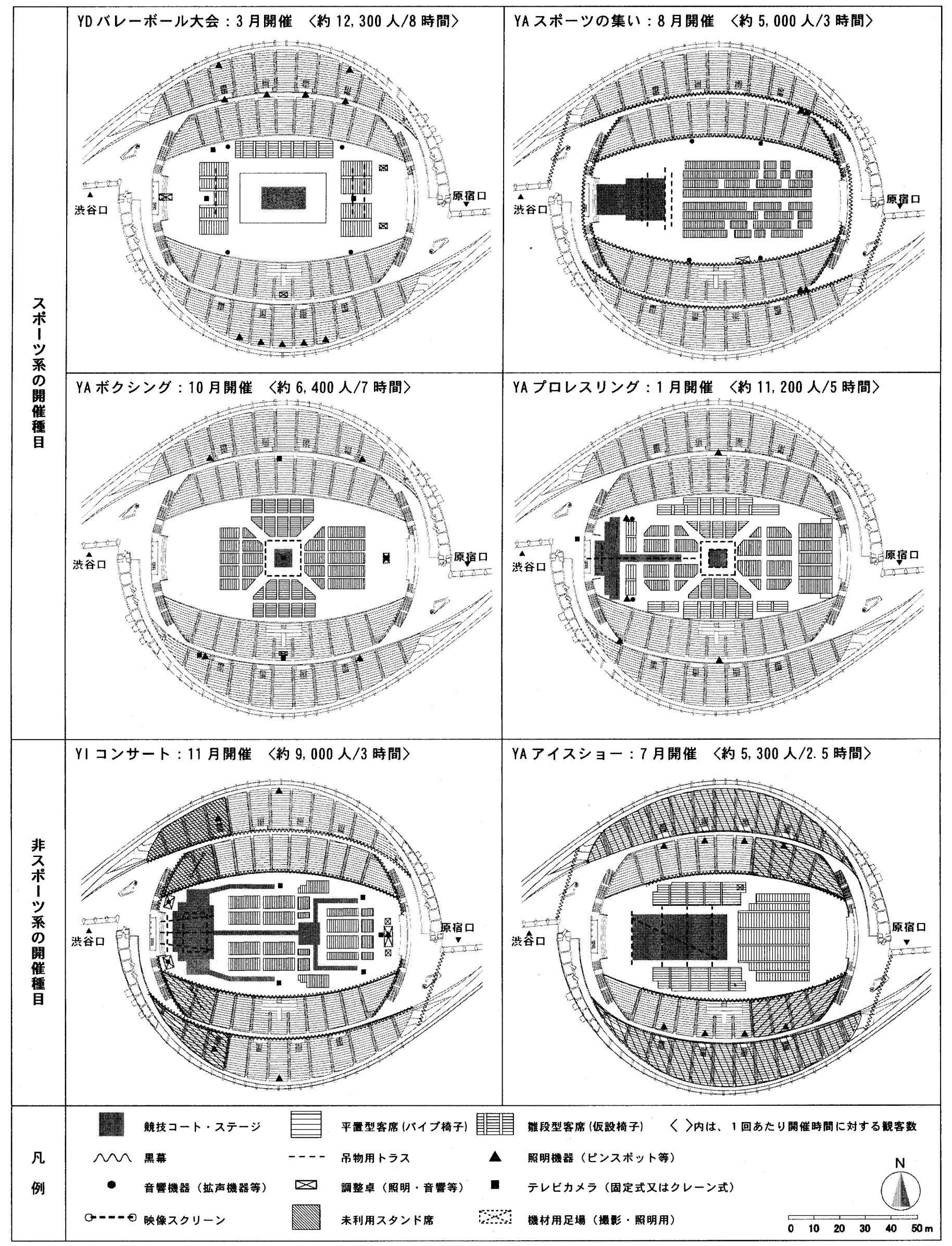

図-7 設営機材の設置場所（模式図） 
種類や設置場所は各所に分散しているが、「非スポーツ系 (特にコ ンサート)」では、それがほぼ同じところに集中している。これは、 前者の設営機材は開催種目別に異なるが、後者では照明・音響・ 映像などの演出機器が共通的な必需品となっているからである。

\section{5- (3) 設営機材の設置場所とアリーナ機能との関係}

アリーナ部分の設営機材で設置頻度が比較的高いものは、コ一 卜・ステージ、アリーナ席、吊物、調整卓、機材用足場の 5 項目 である。ここでは、それら設営機材を共通的に設置していたバレ 一ボールやコンサートなど 6 種類の開催種目を取り上げ、その設 置場所や設置方法、アリーナ機能との関係性を分析する。（前頁） 図-7は、設営機材を平面図に重ねて模式図化したものである。

(1)コート・ステージの設置場所と床荷重との関係 : コートはアリ 一ナ中央、ステージはアリーナ西側（渋谷口側）に設置されるも のが多い。これはロイヤル席がアリーナ正面に位置すること、メ インアプローチが原宿口側に設定されていることに起因する。ア リーナの床荷重は、旧プール部分が平方米あたり $300 \mathrm{~kg}$ 程度、そ の周辺が地耐力程度 (平方米あたり $2 \sim 3$ トン) である。ステージ 全体の重量は、平方米あたり数百キロに及ぶ場合がある。そのた め、設置にはなるべく旧プール部分を避けている。しかし、それ が旧プール部分に重なり、その重量が平方米あたり $300 \mathrm{~kg}$ を超え る場合には、床に荷重分散用の支持部材を設けて対応している。 アリ一ナ床には、設営機材用の耐荷重が必要であることが判る。 (2)アリーナ席の設置場所とスタンド席からの視界との関係 : アリ 一ナ席には、既製椅子による平置型客席と、仮設組み立てによる 雏段型客席がある。それらは、コートやステージに対して「コの 字型」「ロの字型」「川の字型」に配置されるものが多い。但し、 コンサートのようにサブステージや花道を設けるときには「クラ スター型」の場合もある。アリ一ナ客席は、避難通路として 1.5 $\mathrm{m}$ から $6 \mathrm{~m}$ の通路巾が確保され、うち、雊段型客席は、スタンド 席からの視界を妨げない位置や高さで設置される。しかし、アイ スショー拄 16 のようにステージを近距離で見せる開催種目では、 ステージ前に多数の雛段型客席を設置し、スタンド席の一部は使 用しない場合もある。因衬第一体育館では、通常の雏段客席 は9段だが、アイスショーでは約 30 段である。開催種目の中には、 スタンド席からの視界を不要とするものもあることが判る。

(3ステージの設置場所と未利用スタンド席との関係 : スタンド席 は全部で 44 ブロックあり、1 ブロックあたり約 200 人（9,079/44） を収容する。しかし、アリ一ナに立体的な大型ステージが設置さ れると、スタンド席の一部には死角が生じ、例えばコンサートの 場合は、平均 10 ブロック（全体の約 2 割）が未利用スタンド席と なる。ステージは未利用スタンド席の範囲を規定することが判る。 (4)吊物の設置場所と吊荷重との関係：トラスなどの吊物は、コー トやステージの上部もしくはその周辺に設置される。アリーナに おける吊物の許容荷重は、吊元数が 10 点、一点あたり $800 \mathrm{~kg}$ 、計 8トンである。そのため、吊物荷重がそれを超える場合は、表一4 の吊物支持用足場を併用し、不足部分を床に負担させている。吊 物荷重は、技術的には、床への負担も可能であることが判る。

(5)仮設照明と建築照明との関係：照明には、既存の建築照明と主 催者が用意する仮設照明がある。建築照明は、主に「スポーツ系」 で使用されるが、テレビ撮影を行うときには仮設照明(ステージ
用・観客用)がアリーナやスタンド席に配置される。また、ボクシ ングやコンサートでは、トラスや足場にも設置される。建築照明 と仮設照明は、開催種目によって使い分けされていることが判る。 (6)音響機器・調整卓・テレビカメラ・映像スクリーンの設置場所 と設置方法との関係 : 音響機器（拡声器やアンプなど）は機材用 足場に装備され、コート外周部やステージ上部に設置される。調 整卓（照明・音響・映像用）は専用架台に装備され、ロイヤル席 やアリーナ中央部またはアリーナ席後方部に設置される。固定式 カメラは機材用足場に装備され、コート外周部やスタンド席・ア リーナ席後方・スタンド通路部分に設置される。映像スクリーン $(6.4 \times 4.9 \mathrm{~m}$ 程度) は機材用足場に装備され、ステージ上部や未利 用スタンド席またはサブステージ上部などに設置される。プロジ エクターは機材用足場に装備され、スクリーン背面のホール側に 設置される。これら機器には機材用足場が必要であることが判る。

\section{6、設営機材と設置領域との関係（2002 年度の場合）}

以上からは開催種目と設営機材との関係が示された。では、設 営機材は、アリーナのどの部分で設置領域を形成しているのかを 見てみる。重量ある大型の設営機材は、建築計画におけるへビ一 デューティゾーン（酷使される部分）の設定に影響するからであ る。表一 5 は調查対象とした開催種目と、寸法が確認された設営 機材を示し、図ー8はそれらを図上に重ねたものである。

(1)「コート・ステージ」の設置領域：格闘技のリング（コート） はアリーナ中央に、コンサートのメインステージはアリーナ西側 （渋谷口側）に集中している。その平均寸法（ステージ上の設営 機材を含む）は、巾 $34 \mathrm{~m} \times$ 奥行 $17 \mathrm{~m} \times$ 高さ $14.3 \mathrm{~m}$ である。巾と奥 行には 2 対 1 のプロポーションが見られ、その高さは天井高（18 m) の約 8 割まで達している。また、設置領域の面積は、アリー ナ面積の約 $14 \%$ である。コンサートのメインステージは、大型の 設営機材で構成され、その設置領域には定型があることが判る。 (2)「雅段型客席」の設置領域：スポーツ系は「口の字型」、非ス ポーツ系は「コの字型」に重なっている。いずれもアリーナ中央 部には無く、スタンド席付近に集中する。雞段型客席の平均寸法 は、スタンド席に平行配置されるものが巾 $40 \mathrm{~m} \times$ 奥行 $7.7 \mathrm{~m} \times$ 高 さ $1.4 \mathrm{~m}$ 、直交配置されるものが巾 $30 \mathrm{~m} \times$ 奥行 $10.8 \mathrm{~m} \times$ 高さ $1.9 \mathrm{~m}$ であり、ほぼ同規模である。これら設置領域の面積は、アリーナ 面積の約 $32 \%$ に相当する。設置領域には定型があることが判る。 (3)「吊物用トラス」の設置領城：主にアリ一ナの西側に集中し、 コート・ステージの設置場所とほぼ一致する。一般的な「一文字

\section{表-5 渭查対象とした開催種目と設営機材}

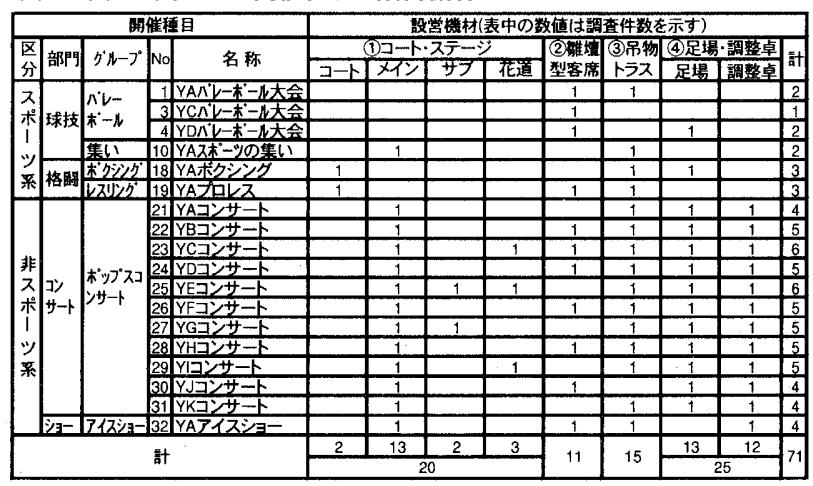




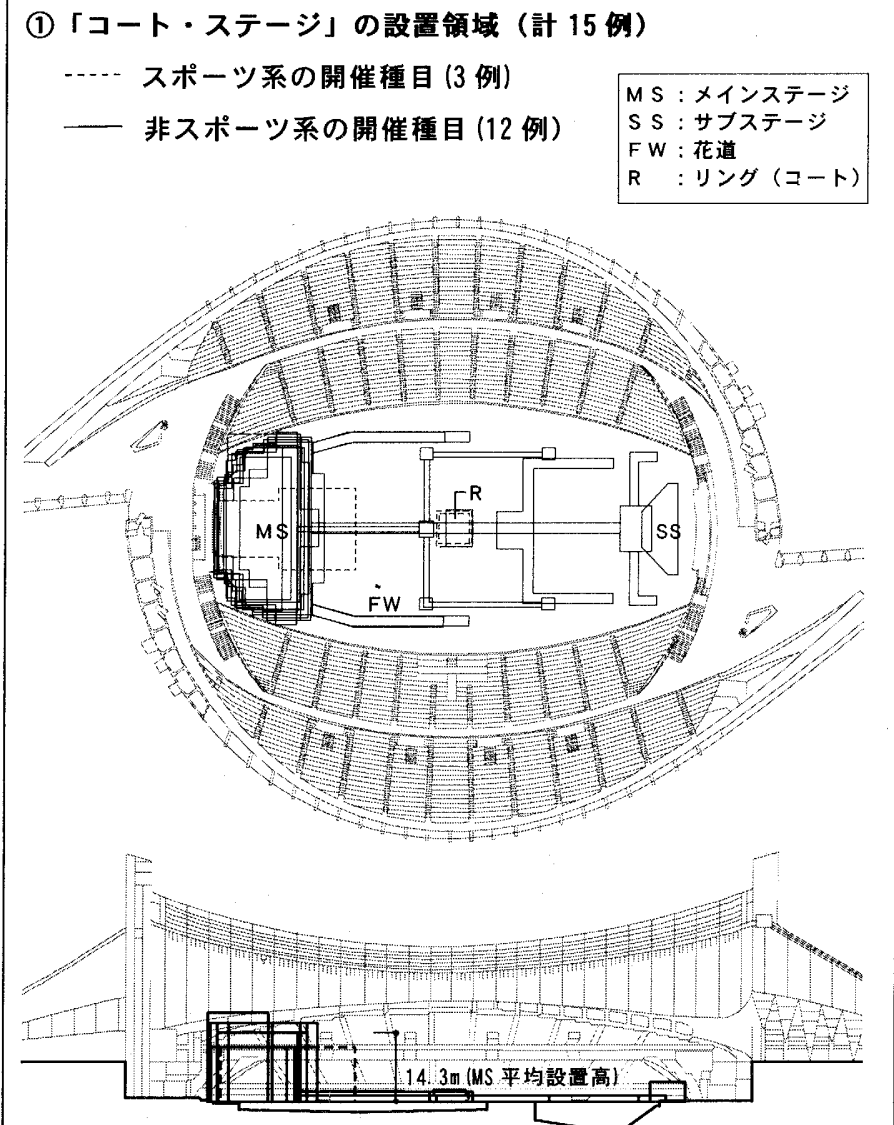

(3)「吊物用トラス」の設置領域（計 15 例）

- スポーツ系の開催種目 (4 例)

、非スポーツ系の開催種目 (11 例)

图中寸法は、非スボ ーツ系におけるー

型トラスの

均設罬高を示す。

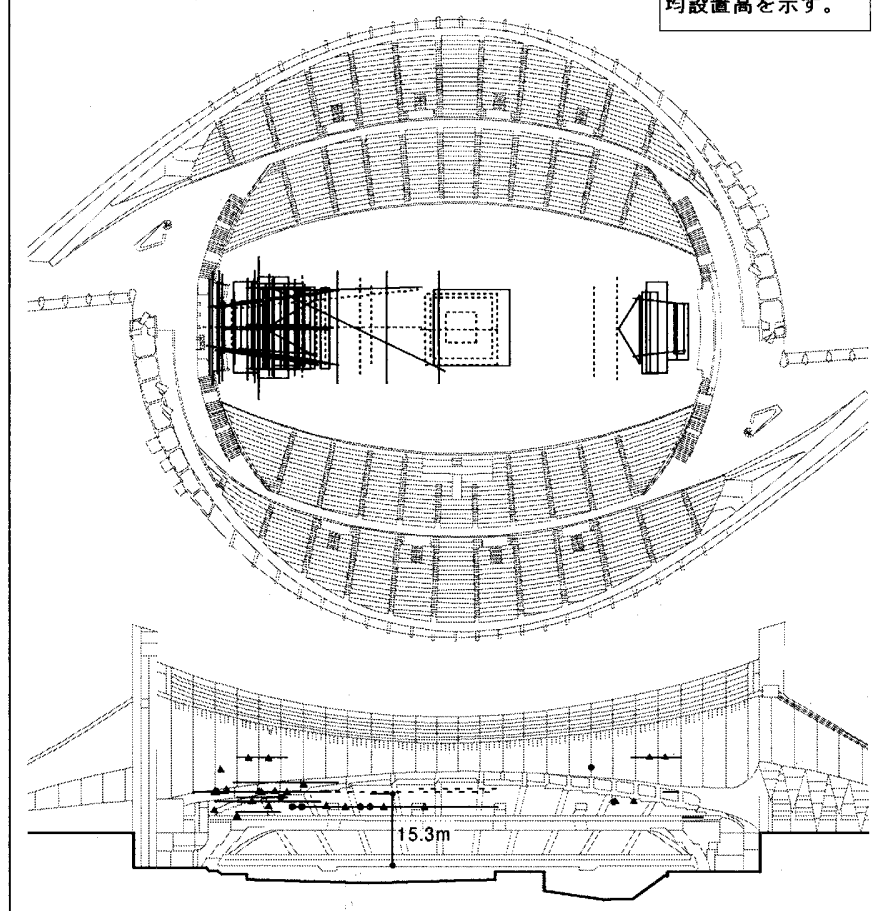

(2)「雅段型客席」の設置領域（計 11 例）
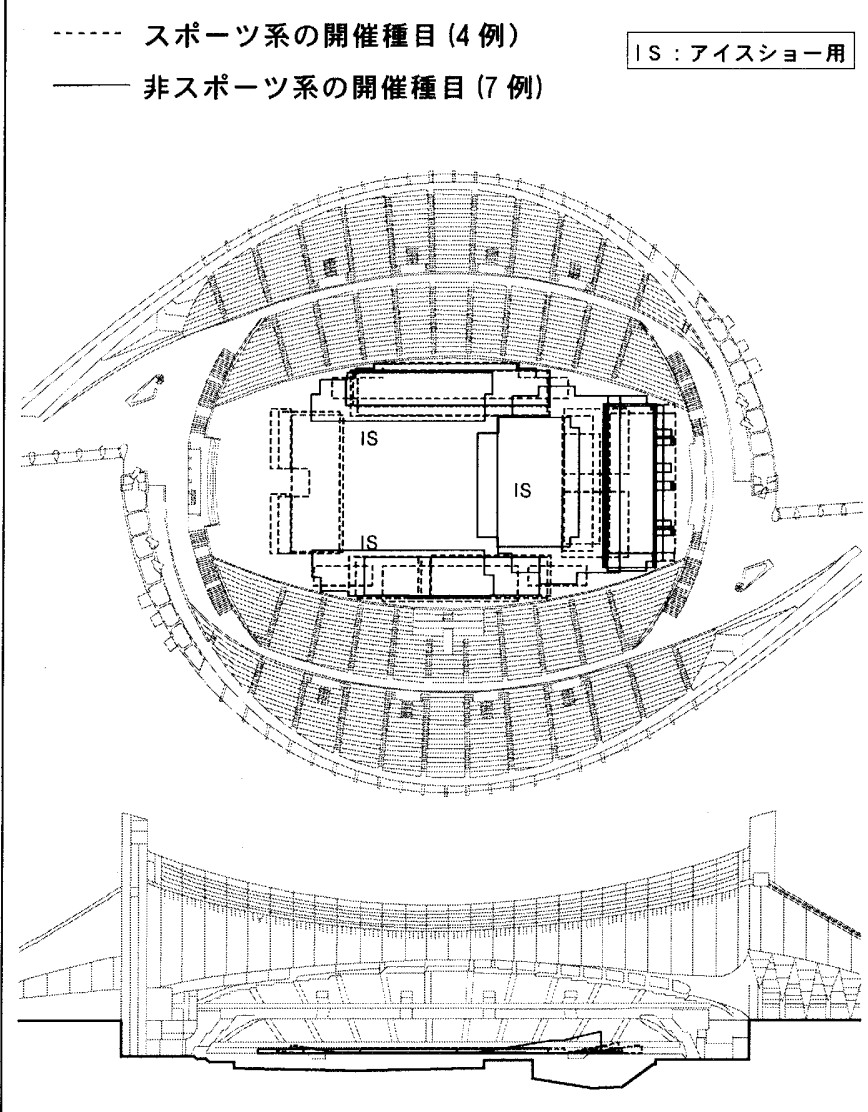

(4)「機材用足場・調整卓」の設置領域（計 14 例）

…スポーッ系の開催種目 (2 例)

— 非スポーツ系の開催種目 (12 例)

口は、機材用足場を

を示す。



各項目の0内は、図上で重ねた開催種目数を示す。 
型トラス」の平均設置高さは、スポーツ系では FL $+13.8 \mathrm{~m}$ 、非ス ポーツ系では FL $+15.3 \mathrm{~m}$ である。非スポーツ系の方がやや高いが、 これは、トラス下に飾り物 (オブジエ) ・ 照明器具・抎声器などを 設置するものが多いからである。それ以外のトラスには、「ロ・ 日・目の字型トラス」や「三角型トラス」がある。そうした各種 トラスの設置領域は、アリーナの短辺寸法に対して概ね $1 / 3$ の範 囲に集中しており、その設置領域の面積は、アリーナ面積の約 $36 \%$ に相当する。トラスの設置領域には定型があることが判る。 (4)「機材用足場・調整卓」の設置領域 : 機材用足場は、左右対称 に設置され、アリーナの東側やスタンド席の西側に集中する。前 者の寸法（币×奥行×高さ：単位m）は、 $2 \times 2 \times 4$ から $4 \times 15 \times 8$ まで あり、アリーナ面積の約 $3 \%$ に相当する。後者の寸法は、 $2 \times 1.5 \times 5$ から $2 \times 3 \times 10$ まであり、その面積はスタンド席の約 20 席分に相当 する。「調整卓」は、平均 2 台設置され、アリーナの中央や東側に 集中する。 $5 \times 3 \times 1.2$ から $7 \times 6 \times 1.2$ まであり、アリーナ面積の約 $2 \%$ に相当する。寸法は様々だが設置領域には定型があることが判る。

7、まとめ : 4、5、6 で得られた知見をまとめ、アリ一ナ空間の有 効活用に関わる計画要件について考察し、今後の研究課題を示す。

「4-(1) 開催種目の変覀」からは、アリーナにおける開催種目は、 体育館の場面に多数存在し、それがアリーナの活用巾を広げてい たが、滑走競技などの一部の開催種目以外は出現・消滅が激しく、 長期間存続するものは少ないことが明らかになった。これは、同 一施設で毎年行われる開催種目は限られていることの現われと見 ることが出来よう。開催種目の存続性の検討は、アリーナ空間を 活用していくときの一計画要件であると考えられる。「4-(2) 2002 年度の開催種目」からは、アリーナ空間はスポーツ関係者が多い 公認競技大会よりも、幅広い客層が多い「スポーツ系」や特化し た客層が多い「非スポーツ系」の開催種目で活用され、年間観客 数や年間施設利用日数が多い開催種目・年間の客席利用率の高い 開催種目がアリーナ空間の活用主体になっている。「非スポーツ 系」の開催種目には収容定員を概ね使い切るものは多いが、設営撤 去や練習（リハーサル）に日数を要するものも多い。以上が明ら かになった。これは、開催種目の観客層・観客数・施設利用日数・ 客席利用率・設営期間等は様々だが、中にはアリーナや観客席を 効率良く使用する開催種目もあることの現われと見ることが出来 よう。開催種目の観客層や観客数・施設利用日数・客席利用率・ 設営期間などの検討は、アリーナ空間を活用していくときの一計 画要件であると考えられる。「5-(2) 設営機材の種類と設置場所 との関係」からは、全開催種目に共通する設営機材は、露出配線・ 電源盤・施設開口部用の暗幕である。施設側の常設備品は少ない が主催者側の持込機材は多い。「非スポーツ系（特にコンサート）」 の設営機材の種類や設置場所には類似するものが多い。以上が明 らかになった。これは、開催種目には、アリーナ空間の各所に電 力供給と暗転装置が必要であること、常設備品と持込機材の使い 分けがあること、類似機材の設営が多いことの現われと見ること が出来よう。設営機材の種類と設置場所の検討は、アリーナ空間 を活用していくときの一計画要件であると考えられる。「5-(3) 設 営機材の設置場所とアリーナ機能との関係」からは、アリーナ床 には設営機材用の耐荷重が必要である。アリーナ上の雛段型客席
は、スタンド席からの視界を妨げない位置や高さで設置されるが、 ステージを近距離で見せる開催種目ではステージ前に多数の雊段 型客席を設け、スタンド席の一部は使用しない場合もある。コー ト・ステージの設置場所はアリーナの正面や玄関の位置で決まる が、逆に未利用スタンド席の範囲を規定する。吊物はコート・ス テージの上部周辺に設置されるが、吊荷重は仮設の吊物支持用足 場を用いて床に負担させることが出来る。建築照明と仮設照明は 開催種目によって使い分けされる。音響機器・調整卓・固定式力 メラ・映像スクリーンの設営には機材用足場が必要である。以上 が明らかになった。これは、開催種目には床の耐荷重・観客席か らの視界・照明の使い分け・機材用足場が必要であることの現わ れと見ることが出来よう。開催種目に必要な床の耐荷重・観客席 からの視界・建築照明の使い分け・機材用足場の設置法などの検 討は、アリーナ空間を活用していくときの一計画要件であると考 えられる。「6、設営機材と設置領域との関係」からは、「コート・ ステージ」・「䌖段型客席」・「吊物用トラス」・「機材用足場・調整 卓」などの大型設営機材の設置領域には、ほぼ定型がある。その 平均的な設置領域の面積は、アリーナ面積に対して、「コート・ス テージ」が約 $14 \%$ 、「雊段型客席」が約 $32 \%$ 、「吊物用トラス」が 約 36\%、「機材用足場」が約 $3 \%$ 、「調整卓」が約 $2 \%$ であ。以 上が明らかになった。これは、アリーナの床面（約 $51 \%$ 注 ${ }^{17}$ ）や 天井面（約 36\%）には、大型設営機材の設置によって、ヘビーデ ユーティゾーンが発生することの現われと見る事が出来よう。大 型設営機材の設置に伴うへビーデューティゾーンの検討は、アリ 一ナ空間を活用していくときの一計画要件であると考えられる。

本編では、アリーナ空間の有効活用に関わる計画要件について、 その一端を考察したが、これ以外にも計画要件はあると思われる。 類似施設を更に調查分析していくことが、今後の研究課題である。

謝辞 本研究への機会を与えてくださった国立代々木競技場の皆様、各種調査でご指導をいただい た信平扶美子様、松田幹弘様、白木義雄様に謝意を表します。

\section{考支献・注积}

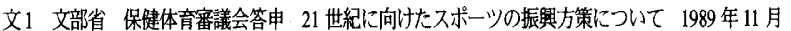

文2 文部省 保健体育審議会答申 生涯にわたる心身の健康の保持增進のための今後の煡康に関す る教育及びスポーツ振興の在り方について 1997 年9月

文3 財) 日本体育施設協会 体育館一プランニングから管理まで (株) 体育施設出版 2000 年 5 月

文4上和田茂 わか国の戦後におりる公共体育館計画の変遷に関する研究 第 15 回地域施設計画シ ンポシ沁么 日本建筑学会 建築計画委員会 地域施設計画小委員会 P.153 160 1997 年 7月

文5矢野裕芳 大規模公共体育施設における多目的利用空間の経年変化に関する研究（国立代々木 競技場第一体育館にお梳るアリ一十利用の変遷) 日本建築学会大会学術講演梗概集（北陸）建筑 計画ＩＰ371〜372 2002年8月」をもとに再整理したものである。

注 1 本研究では「競技大会用の施設各部を各種の開催種目で活用していくこと」を有効活用と言う。 注2 本研究では「施設の運営条件・設計条件を設定する際の要件のこと」を計画要件と言う。

注 3 本研究では「主催関保者が使用する会議室・更衣室・選手控室など」を主催関係者用のサービス 空間と言う。それら諸室を各種の開催種目で多目的利用する場合の対応法情二編で詳述する。 注4 本研究では「屋外の園地 (プラザ)・駐車場・バックヤードなど」を外部空間と言う。

注 5 建設当初の施設名は、国立屋内総合競技場であった。

注6 オリンピックの後利用として、水泳場・アイススケート場・体育館が想定されたアリーナである。 注 7 施設活用により収益を上げることを目指している。(月間国立競技場第 1号 P2 1958年12月） 注8 施設面では防火設備や空調設備を整備している。運営面では施設利用規定を改定している。 注 9 建築学会特別賞・建設業協会賞などを受賞している。

注 10 当初より一企業体としての運営が求められているという点で類稀な大規模公共体育館である。 注 11 旧プールは現在使用されておらず、アリーナは体育館として恒久的に模槏替えされている。 注 12 倉庫・機材搬入口・機械室などの管理諸室は、スタンド席下部や下屋部分に位置している。 注 13 区別は資料の分析結果による。主な変遷理由は利用者の隇少や施設利用規定の改定である。 注 14 本研究では「開催種目別の施設利用日数に対する観客数の割合のこと」を客席利用率と言う。 注 15 本文中の事例数と図中のプロット数は異なって見えるが、図中では重複籄所があるからである。 注 16 体育館の床は、コンクリート床・根太パネル・仕上パネルの3 層で構成される。アイスリンクヘ は、仕上パネルを澈去後、根太パネル上に冷媒管を敷設し、散水・製米し、場面転換している。 注 17 「吊物用トラス」を除く合計值である。残り 49\%はは避難通路や平置型客席などで使用される。 